4

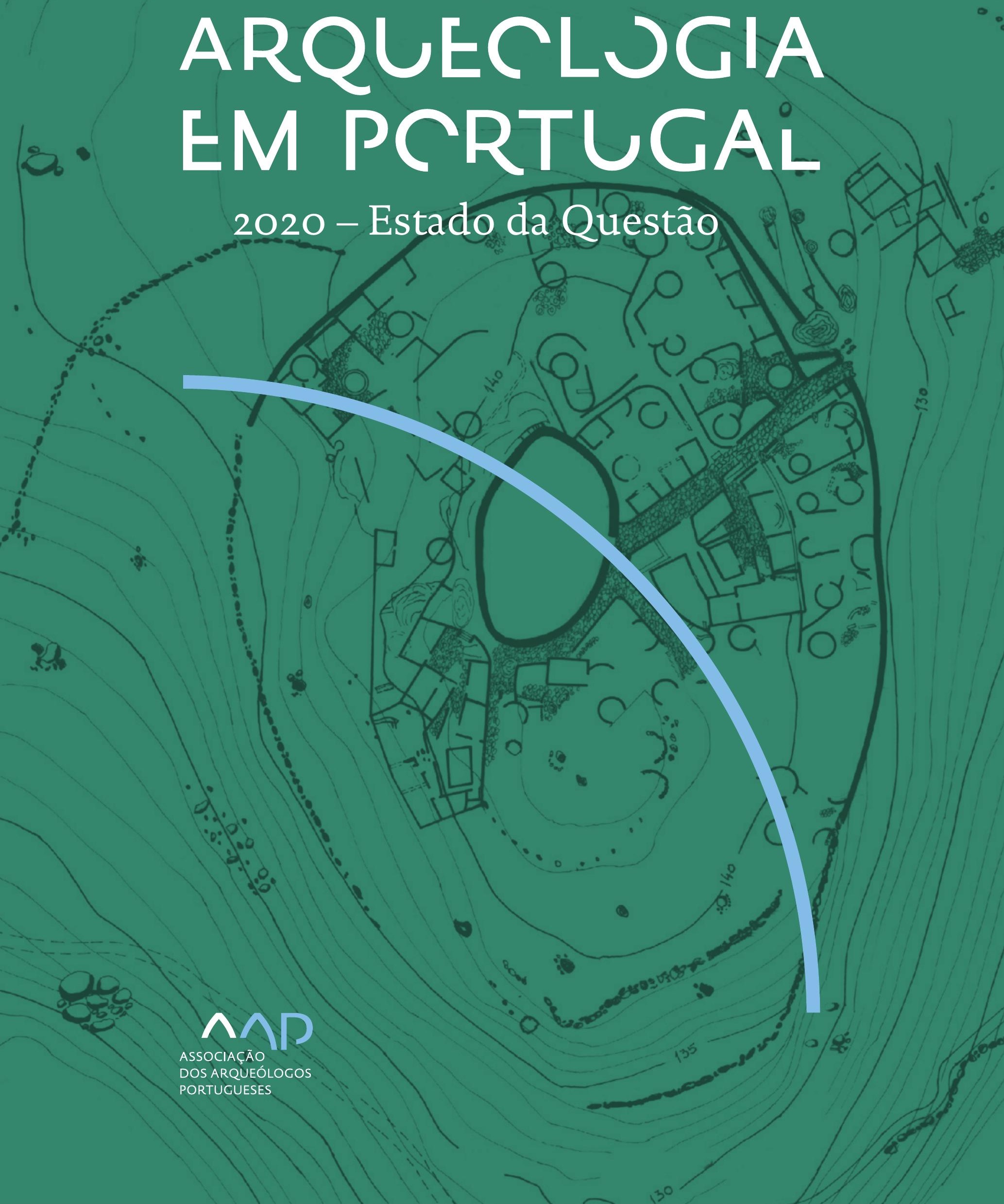


Coordenação editorial: José Morais Arnaud, César Neves e Andrea Martins Design gráfico: Flatland Design

AAP - ISBN: 978-972-9451-89-8

CITCEM - ISBN: 978-989-8970-25-1

Associação dos Arqueólogos Portugueses e CITCEM

Lisboa, 2020

O conteúdo dos artigos é da inteira responsabilidade dos autores. Sendo assim a Associação dos Arqueólogos Portugueses declina qualquer responsabilidade por eventuais equívocos ou questões de ordem ética e legal.

Desenho de capa:

Planta do castro de Monte Mozinho (Museu Municipal de Penafiel).

\section{$\hat{\wedge} \mathrm{P}$}

DOS ARQUEÓLOGOS PORTUGUESES

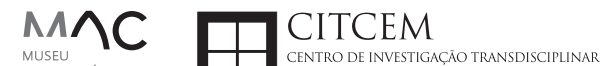
MUSEU
ARQUELLÓGICO
DO CARMO
U.PORTO

FLUP FACULDADE DE LETRAS
UNIVERSIDADE DO PORTO

Apoio

EC para a Ciência 


\section{Índice}

15 Prefácio

José Morais Arnaud

\section{Historiografia e Teoria}

17 Território, comunidade, memória e emoção: a contribuição da história da arqueologia (algumas primeiras e breves reflexões)

Ana Cristina Martins

25 Como descolonizar a arqueologia portuguesa?

Rui Gomes Coelho

41 Arqueologia e Modernidade: uma revisitação pessoal e breve de alguns aspetos da obra homónima de Julian Thomas de 2004

Vítor Oliveira Jorge

57 Dados para a História das Mulheres na Arqueologia portuguesa, dos finais do século XIX aos inícios do século XX: números, nomes e tabelas

Filipa Dimas / Mariana Diniz

73 Retractos da arqueologia portuguesa na imprensa: (in)visibilidades no feminino

Catarina Costeira / Elsa Luís

85 Arqueologia e Arqueólogos no Norte de Portugal Jacinta Bugalhão

101 Vieira Guimarães (1864-1939) e a arqueologia em Tomar: uma abordagem sobre o território e as gentes

João Amendoeira Peixoto / Ana Cristina Martins

115 Os memoráveis? A arqueologia algarvia na imprensa nacional e regional na presente centúria (2001-2019): características, visões do(s) passado(s) e a arqueologia

enquanto marca

Frederico Agosto / João Silva

129 A Evolução da Arqueologia Urbana e a Valorização Patrimonial no Barlavento Algarvio: Os casos de Portimão e Silves

Artur Mateus / Diogo Varandas / Rafael Boavida

\section{Gestão, Valorização e Salvaguarda do Património}

145 O Caderno Reivindicativo e as condições de trabalho em Arqueologia Miguel Rocha / Liliana Matias Carvalho / Regis Barbosa / Mauro Correia / Sara Simões / Jacinta Bugalhão / Sara Brito / Liliana Veríssimo Carvalho / Richard Peace / Pedro Peça / Cézer Santos

155 Os Estudos de Impacte Patrimonial como elemento para uma estratégia sustentável de minimização de impactes no âmbito de reconversões agrícolas Tiago do Pereiro

165 Salvaguarda de Património arqueológico em operações florestais: gestão e sensibilização Filipa Bragança / Gertrudes Zambujo / Sandra Lourenço / Belém Paiva / Carlos Banha / Frederico Tatá Regala / Helena Moura / Jacinta Bugalhão / João Marques / José Correia / Pedro Faria / Samuel Melro

179 Os valores do Património: uma investigação sobre os Sítios Pré-históricos de Arte Rupestre do Vale do Rio Côa e de Siega Verde José Paulo Francisco 
189 Conjugando recursos arqueológicos e naturais para potenciar as visitas ao Geoparque Litoral de Viana do Castelo (Noroeste de Portugal)

Hugo A. Sampaio / Ana M.S. Bettencourt / Susana Marinho / Ricardo Carvalhido

203 Áreas de Potencial Arqueológico na Região do Médio Tejo: Modelo Espacial Preditivo Rita Ferreira Anastácio / Ana Filipa Martins / Luiz Oosterbeek

223 Património Arqueológico e Gestão Territorial: O contributo da Arqueologia para a revisão do PDM de Avis

Ana Cristina Ribeiro

237 A coleção arqueológica do extinto Museu Municipal do Porto - Origens, Percursos e Estudos

Sónia Couto

251 Valpaços - uma nova carta arqueológica

Pedro Pereira / Maria de Fátima Casares Machado

263 Arqueologia na Cidade de Peniche

Adriano Constantino / Luís Rendeiro

273 Arqueologia Urbana: a cidade de Lagos como caso de Estudo Cátia Neto

285 Estratégias de promoção do património cultural subaquático nos Açores. O caso da ilha do Faial

José Luís Neto / José Bettencourt / Luís Borges / Pedro Parreira

297 Carta Arqueológica da Cidade Velha: Uma primeira abordagem

Jaylson Monteiro / Nireide Tavares / Sara da Veiga / Claudino Ramos / Edson Brito /

Carlos Carvalho / Francisco Moreira / Adalberto Tavares

311 Antropologia Virtual: novas metodologias para a análise morfológica e funcional Ricardo Miguel Godinho / Célia Gonçalves

\section{Didáctica da Arqueologia}

327 Como os projetos de Arqueologia podem contribuir para uma comunidade culturalmente mais consciente Alexandra Figueiredo / Claúdio Monteiro / Adolfo Silveira / Ricardo Lopes

337 Educação Patrimonial - Um cidadão esclarecido é um cidadão ativo! Ana Paula Almeida

351 A aproximação da Arqueologia à sala de aula: um caso de estudo no $3^{\circ}$ ciclo do Ensino Básico Luís Serrão Gil

363 Arqueologia 3.o - Pensar e comunicar a Arqueologia para um futuro sustentável Mónica Rolo

377 “Conversa de Arqueólogos" - Divulgar a Arqueologia em tempos de Pandemia Diogo Teixeira Dias

389 Escola Profissional de Arqueologia: desafios e oportunidades Susana Nunes / Dulcineia Pinto / Júlia Silva / Ana Mascarenhas

399 Os Museus de Arqueologia e os Jovens: a oferta educativa para o público adolescente Beatriz Correia Barata / Leonor Medeiros

411 O museu universitário como mediador entre a ciência e a sociedade: o exemplo da secção de arqueologia no Museu de História Natural e da Ciência da Universidade do Porto (MHNC-UP)

Rita Gaspar 
421 Museu de Lanifícios: Real Fábrica de Panos. Atividades no âmbito da Arqueologia Beatriz Correia Barata / Rita Salvado

427 Arqueologia Pública e o caso da localidade da Mata (Torres Novas) Cláudia Manso / Ana Rita Ferreira / Cristiana Ferreira / Vanessa Cardoso Antunes

431 Do sítio arqueológico ao museu: um percurso (também) didático Lídia Fernandes

447 Estão todos convidados para a Festa! E para dançar também... O projecto do Serviço Educativo do Museu Arqueológico do Carmo na $5^{\underline{a}}$ Edição da Festa da Arqueologia Rita Pires dos Santos

459 O “Clã de Carenque”, um projeto didático de arqueologia Eduardo Gonzalez Rocha

469 Mediação cultural: peixe que puxa carroça nas Ruínas Romanas de Troia Inês Vaz Pinto / Ana Patrícia Magalhães / Patrícia Brum / Filipa Santos

481 Didática Arqueológica, experiências do Projeto Mértola Vila Museu Maria de Fátima Palma / Clara Rodrigues / Susana Gómez / Lígia Rafael

\section{Arte Rupestre}

497 Os inventários de arte rupestre em Portugal Mila Simões de Abreu

513 O projeto FIRST-ART - conservação, documentação e gestão das primeiras manifestações de arte rupestre no Sudoeste da Península Ibérica: as grutas do Escoural e Maltravieso Sara Garcês / Hipólito Collado / José Julio García Arranz / Luiz Oosterbeek / António Carlos Silva / Pierluigi Rosina / Hugo Gomes / Anabela Borralheiro Pereira / George Nash / Esmeralda Gomes / Nelson Almeida / Carlos Carpetudo

523 Trabalhos de documentação de arte paleolítica realizados no âmbito do projeto PalæoCôa André Tomás Santos / António Fernando Barbosa / Luís Luís / Marcelo Silvestre / Thierry Aubry

537 Imagens fantasmagóricas, silhuetas elusivas: as figuras humanas na arte do Paleolítico Superior da região do Côa Mário Reis

$55^{1}$ Os motivos zoomórficos representados nas placas de tear de Vila Nova de São Pedro (Azambuja, Portugal) Andrea Martins / César Neves / José M. Arnaud / Mariana Diniz

571 Arte Rupestre do Monte de Góios (Lanhelas, Caminha). Síntese dos resultados dos trabalhos efectuados em 2007-2009 Mário Varela Gomes

599 Gravuras rupestres de barquiformes no Monte de S. Romão, Guimarães, Noroeste de Portugal Daniela Cardoso

613 Círculos segmentados gravados na Bacia do Rio Lima (Noroeste de Portugal): contributos para o seu estudo Diogo Marinho / Ana M.S. Bettencourt / Hugo Aluai Sampaio

631 Equídeos gravados no curso inferior do Rio Mouro, Monção (NW Portugal). Análise preliminar Coutinho, L.M. / Bettencourt, A.M.S / Sampaio, Hugo A.S

645 Paletas na Arte Rupestre do Noroeste de Portugal. Inventário preliminar Bruna Sousa Afonso / Ana M. S. Bettencourt / Hugo A. Sampaio 


\section{Pré-História}

661 O projeto Miño/Minho: balanço de quatro anos de trabalhos arqueológicos Sérgio Monteiro-Rodrigues / João Pedro Cunha-Ribeiro / Eduardo Méndez-Quintas / Carlos Ferreira / Pedro Xavier / José Meireles / Alberto Gomes / Manuel Santonja / Alfredo Pérez-González

677 A ocupação paleolítica da margem esquerda do Baixo Minho: a indústria lítica do sítio de Pedreiras 2 (Monção, Portugal) e a sua integração no contexto regional Carlos Ferreira / João Pedro Cunha-Ribeiro / Sérgio Monteiro-Rodrigues / Eduardo Méndez-Quintas / Pedro Xavier / José Meireles / Alberto Gomes / Manuel Santonja / Alfredo Pérez-González

693 O sítio acheulense do Plistocénico médio da Gruta da Aroeira Joan Daura / Montserrat Sanz / Filipa Rodrigues / Pedro Souto / João Zilhão

703 As sociedades neandertais no Barlavento algarvio: modelos preditivos com recurso aos SIG

Daniela Maio

715 A utilização de quartzo durante o Paleolítico Superior no território dos vales dos rios Vouga e Côa

Cristina Gameiro / Thierry Aubry / Bárbara Costa / Sérgio Gomes / Luís Luís / Carmen Manzano / André Tomás Santos

733 Uma perspetiva diacrónica da ocupação do concheiro do Cabeço da Amoreira (Muge, Portugal) a partir da tecnologia lítica Joana Belmiro / João Cascalheira / Célia Gonçalves

745 Novos dados sobre a Pré-história Antiga no concelho de Palmela. A intervenção arqueológica no sítio do Poceirão I

Michelle Teixeira Santos

757 Problemas em torno de Datas Absolutas Pré-Históricas no Norte do Alentejo Jorge de Oliveira

771 Povoamento pré-histórico nas áreas montanhosas do NO de Portugal: o Abrigo 1 de Vale de Cerdeira Pedro Xavier / José Meireles / Carlos Alves

783 Apreciação do povoamento do Neolítico Inicial na Baixa Bacia do Douro. A Lavra I (Serra da Aboboreira) como caso de estudo Maria de Jesus Sanches

797 O Processo de Neolitização na Plataforma do Mondego: os dados do Sector C do Outeiro dos Castelos de Beijós (Carregal do Sal)

João Carlos de Senna-Martinez / José Manuel Quintã Ventura / Andreia Carvalho / Cíntia Maurício

823 Novos trabalhos na Lapa da Bugalheira (Almonda, Torres Novas) Filipa Rodrigues / Pedro Souto / Artur Ferreira / Alexandre Varanda / Luís Gomes / Helena Gomes / João Zilhão

837 A pedra polida e afeiçoada do sítio do Neolítico médio da Moita do Ourives (Benavente, Portugal)

César Neves

857 Casal do Outeiro (Encarnação, Mafra): novos contributos para o conhecimento do povoamento do Neolítico final na Península de Lisboa.

Cátia Delicado / Carlos Maneira e Costa / Marta Miranda / Ana Catarina Sousa

873 Stresse infantil, morbilidade e mortalidade no sítio arqueológico do Neolítico Final/ Calcolítico ( $4^{\circ}$ e $3^{\circ}$ milénio a.C.) do Monte do Carrascal 2 (Ferreira do Alentejo, Beja) Liliana Matias de Carvalho / Sofia N. Wasterlain 
885 Come together: O Conjunto Megalítico das Motas (Monção, Viana do Castelo) e as expressões Campaniformes do Alto Minho Ana Catarina Basílio / Rui Ramos

899 Trabalhos arqueológicos no sítio Calcolítico da Pedreira do Poio Carla Magalhães / João Muralha / Mário Reis / António Batarda Fernandes

913 O sítio arqueológico de Castanheiro do Vento. Da arquitectura do sítio à arquitectura de um território João Muralha Cardoso

925 Estudo zooarqueológico das faunas do Calcolítico final de Vila Nova de São Pedro (Azambuja, Portugal): Campanhas de 2017 e 2018 Cleia Detry / Ana Catarina Francisco / Mariana Diniz / Andrea Martins / César Neves / José Morais Arnaud

943 As faunas depositadas no Museu Arqueológico do Carmo provenientes de Vila Nova de São Pedro (Azambuja): as campanhas de 1937 a 1967 Ana Catarina Francisco / Cleia Detry / César Neves / Andrea Martins / Mariana Diniz / José Morais Arnaud

959 Análise funcional de material lítico em sílex do castro de Vila Nova de S. Pedro (Azambuja, Portugal): uma primeira abordagem Rafael Lima

971 O recinto da Folha do Ouro 1 (Serpa) no contexto dos recintos de fossos calcolíticos alentejanos

António Carlos Valera / Tiago do Pereiro / Pedro Valério / António M. Monge Soares

\section{Proto-História}

987 Produção de sal marinho na Idade do Bronze do noroeste Português. Alguns dados para uma reflexão

Ana M. S. Bettencourt / Sara Luz / Nuno Oliveira / Pedro P. Simões / Maria Isabel C. Alves / Emílio Abad-Vidal

1001 A estátua-menir do Pedrão ou de São Bartolomeu do Mar (Esposende, noroeste de Portugal) no contexto arqueológico da fachada costeira de entre os rios Neiva e Cávado Ana M. S. Bettencourt / Manuel Santos-Estévez / Pedro Pimenta Simões / Luís Gonçalves

1015 O Castro do Muro (Vandoma/Baltar, Paredes) - notas para uma biografia de ocupação da Idade do Bronze à Idade Média

Maria Antónia D. Silva / Ana M. S. Bettencourt / António Manuel S. P. Silva / Natália Félix

1031 Do Bronze Final à Idade Média - continuidades e hiatos na ocupação de Povoados em Oliveira de Azeméis João Tiago Tavares / Adriaan de Man

1041 As faunas do final da Idade do Bronze no Sul de Portugal: leituras desde o Outeiro do Circo (Beja)

Nelson J. Almeida / Íris Dias / Cleia Detry / Eduardo Porfírio / Miguel Serra

1055 A Espada do Monte das Oliveiras (Serpa) - uma arma do Bronze Pleno do Sudoeste Rui M. G. Monge Soares / Pedro Valério / Mariana Nabais / António M. Monge Soares

1065 São Julião da Branca (Albergaria-a-Velha) - Investigação e valorização de um povoado do Bronze Final

António Manuel S. P. Silva / Paulo A. P. Lemos / Sara Almeida e Silva / Edite Martins de Sá

1083 Do castro de S. João ao Mosteiro de Santa Clara: notícia de uma intervenção arqueológica, em Vila do Conde Rui Pinheiro 
1095 O castro de Ovil (Espinho), um quarto de século de investigação - resultados e questões em aberto

Jorge Fernando Salvador / António Manuel S. P. Silva

1111 O Castro de Salreu (Estarreja), um povoado proto-histórico no litoral do Entre Douro e Vouga

Sara Almeida e Silva / António Manuel S. P. Silva / Paulo A. P. Lemos / Edite Martins de Sá

1127 Castro de Nossa Senhora das Necessidades (Sernancelhe): uma primeira análise artefactual Telma Susana O. Ribeiro

${ }_{1141}$ A cividade de Bagunte. O estado atual da investigação Pedro Brochado de Almeida

1153 Zoomorfos na cerâmica da Idade do Ferro no NW Peninsular: inventário, cronologias e significado Nuno Oliveira / Cristina Seoane

1163 Vasos gregos em Portugal: diferentes maneiras de contar a história do intercâmbio cultural na Idade do Ferro

Daniela Ferreira

1175 Os exotica da necrópole da Idade do Ferro do Olival do Senhor dos Mártires (Alcácer do Sal) no seu contexto regional

Francisco B. Gomes

\section{Antiguidade Clássica e Tardia}

1191 O uso de madeira como combustível no sítio da Quinta de Crestelos (Baixo Sabor): da Idade do Ferro à Romanização Filipe Vaz / João Tereso / Sérgio Simões Pereira / José Sastre / Javier Larrazabal Galarza / Susana Cosme / José António Pereira / Israel Espi

1207 Cultivos de Época Romana no Baixo Sabor: continuidade em tempos de mudança? João Pedro Tereso / Sérgio Simões Pereira / Filipe Santos / Luís Seabra / Filipe Vaz

1221 A casa romana na Hispânia: aplicação dos modelos itálicos nas províncias ibéricas Fernanda Magalhães / Diego Machado / Manuela Martins

1235 As pinturas murais romanas da Rua General Sousa Machado, n. ${ }^{5}$ 1, Chaves José Carvalho

1243 Trás do Castelo (Vale de Mir, Pegarinhos, Alijó) - Uma exploração agrícola romana do Douro

Tony Silvino / Pedro Pereira

1255 A sequência de ocupação no quadrante sudeste de Bracara Augusta: as transformações de uma unidade doméstica Lara Fernandes / Manuela Martins

1263 Os Mosaicos com decoração geométrica e geométrico-vegetalista dos sítios arqueológicos da área do Conuentus Bracaraugustanus. Novas abordagens quanto à conservação, restauro, decoração e datação Maria de Fátima Abraços / Licínia Wrench

1277 “Casa Romana” do Castro de São Domingos (Cristelos, Lousada): Escavação, Estudo e Musealização Paulo André de P. Lemos

1291 A arqueobotânica no Castro de Guifões (Matosinhos, Noroeste de Portugal): O primeiro estudo carpológico

Luís Seabra / Andreia Arezes / Catarina Magalhães / José Varela / João Pedro Tereso 
1305 Um Horreum Augustano na Foz do Douro (Monte do Castelo de Gaia, Vila Nova de Gaia) Rui Ramos

1311 Ponderais romanos na Lusitânia: padrões, formas, materiais e contextos de utilização Diego Barrios Rodríguez

1323 Um almofariz centro-itálico na foz do Mondego

Marco Penajoia

1335 Estruturas romanas de Carnide - Lisboa Luísa Batalha / Mário Monteiro / Guilherme Cardoso

1347 O contexto funerário do sector da "necrópole NO" da Rua das Portas de S. Antão (Lisboa): o espaço, os artefactos, os indivíduos e a sua interconectividade na interpretação do passado Sílvia Loja, José Carlos Quaresma, Nelson Cabaço, Marina Lourenço, Sílvia Casimiro, Rodrigo Banha da Silva, Francisca Alves-Cardoso

${ }_{1361}$ Povoamento em época Romana na Amadora - resultados de um projeto pluridisciplinar Gisela Encarnação / Vanessa Dias

1371 A Arquitectura Residencial em Mirobriga (Santiago do Cacém): contributo a partir de um estudo de caso Filipe Sousa / Catarina Felício

${ }_{1385}$ O fim do ciclo. Saneamento e gestão de resíduos nos edifícios termais de Mirobriga (Santiago do Cacém)

Catarina Felício / Filipe Sousa

1399 Balsa, Topografia e Urbanismo de uma Cidade Portuária Vítor Silva Dias / João Pedro Bernardes / Celso Candeias / Cristina Tété Garcia

1413 No Largo das Mouras Velhas em Faro (2017): novas evidências da necrópole norte de Ossonoba e da sua ocupação medieval Ricardo Costeira da Silva / Paulo Botelho / Fernando Santos / Liliana Nunes

1429 Instrumentos de pesca recuperados numa fábrica de salga em Ossonoba (Faro) Inês Rasteiro / Ricardo Costeira da Silva / Paulo Botelho

1439 A Necrópole Romana do Eirô, Duas Igrejas (Penafiel): intervenção arqueológica de 2016 Laura Sousa / Teresa Soeiro

1457 Ritual, descarte ou afetividade? A presença de Canis lupus familiaris na Necrópole Noroeste de Olisipo (Lisboa)

Beatriz Calapez Santos / Sofia Simões Pereira / Rodrigo Banha da Silva / Sílvia Casimiro / Cleia Detry / Francisca Alves Cardoso

1467 Dinâmicas económicas em Bracara na Antiguidade Tardia Diego Machado / Manuela Martins / Fernanda Magalhães / Natália Botica

1479 Cerâmicas e Vidros da Antiguidade Tardia do Edifício sob a Igreja do Bom Jesus (Vila Nova de Gaia) Joaquim Filipe Ramos

1493 Novos contributos para a topografia histórica de Mértola no período romano e na Antiguidade Tardia Virgílio Lopes

\section{8. Época Medieval}

1511 Cerâmicas islâmicas no Garb setentrional "português": algumas evidências e incógnitas Constança dos Santos / Helena Catarino / Susana Gómez / Maria José Gonçalves / Isabel Inácio / Gonçalo Lopes / Jacinta Bugalhão / Sandra Cavaco / Jaquelina Covaneiro / Isabel Cristina Fernandes / Ana Sofia Gomes 
1525 Contributo para o conhecimento da cosmética islâmica, em Silves, durante a Idade Média Rosa Varela Gomes

1537 Yábura e o seu território - uma análise histórico-arqueológica de Évora entre os séculos VIII-XII José Rui Santos

1547 A encosta sul do Castelo de Palmela - resultados preliminares da escavação arqueológica Luís Filipe Pereira / Michelle Teixeira Santos

1559 A igreja de São Lourenço (Mouraria, Lisboa): um conjunto de silos e de cerâmica medieval islâmica

Andreia Filipa Moreira Rodrigues

1571 O registo material de movimentações populacionais no Médio Tejo, durante os séculos XII-XIII. Dois casos de "sunken featured buildings", nos concelhos de Cartaxo e Torres Novas Marco Liberato / Helena Santos / Nuno Santos

1585 O nordeste transmontano nos alvores da Idade média. Notas para reflexão Ana Maria da Costa Oliveira

1601 Sepulturas escavadas na rocha do Norte de Portugal e do Vale do Douro: primeiros resultados do Projecto SER-NPVD

Mário Jorge Barroca / César Guedes / Andreia Arezes / Ana Maria Oliveira

1619 "Portucalem Castrum Novum" entre o Mediterrâneo e o Atlântico: o estudo dos materiais cerâmicos alto-medievais do arqueossítio da rua de D. Hugo, nํ. 5 (Porto) João Luís Veloso

1627 A Alta Idade Média na fronteira de Lafões: notas preliminares sobre a Arqueologia no Concelho de Vouzela

Manuel Luís Real / Catarina Tente

1641 Um conjunto cerâmico medieval fora de portas: um breve testemunho aveirense Susana Temudo

${ }_{1651}$ Os Lóios do Porto: uma perspetiva integrada no panorama funerário da Baixa Idade Média à Época Moderna em meios urbanos em Portugal

Ana Lema Seabra

1659 O Caminho Português Interior de Santiago como eixo viário na Idade Média Pedro Azevedo

1665 Morfologia Urbana: Um exercício em torno do Castelo de Ourém André Donas-Botto / Jaqueline Pereira

1677 Intervenção arqueológica na Rua Marquês de Pombal/Largo do Espírito Santo (Bucelas, Loures)

Florbela Estêvão / Nathalie Antunes-Ferreira / Dário Ramos Neves / Inês Lisboa

1691 O Cemitério Medieval do Poço do Borratém e a espacialidade funerária na cidade de Lisboa Inês Belém / Vanessa Filipe / Vasco Noronha Vieira / Sónia Ferro / Rodrigo Banha da Silva

1705 Um Espaço Funerário Conventual do séc. XV em Lisboa: o caso do Convento de São Domingos da Cidade Sérgio Pedroso / Sílvia Casimiro / Rodrigo Banha da Silva / Francisca Alves Cardoso

\section{9. Época Moderna e Contemporânea}

1721 Arqueologia Moderna em Portugal: algumas reflexões críticas em torno da quantificação de conjuntos cerâmicos e suas inferências históricas e antropológicas Rodrigo Banha da Silva / André Bargão / Sara da Cruz Ferreira

1733 Faianças de dois contextos entre os finais do século XVI e XVIII do Palácio dos Condes de Penafiel, Lisboa

Martim Lopes / Tomás Mesquita 
1747 Um perfil de consumo do século XVIII na foz do Tejo: O caso do Mercado da Ribeira, Lisboa Sara da Cruz Ferreira / Rodrigo Banha da Silva / André Bargão

1761 Os Cachimbos dos Séculos XVII e XVIII do Palácio Mesquitela e Convento dos Inglesinhos (Lisboa)

Inês Simão / Marina Pinto / João Pimenta / Sara da Cruz Ferreira / André Bargão / Rodrigo Banha da Silva

1775 "Tomar os fumos da erua que chamão em Portugal erua sancta». Estudo de Cachimbos provenientes da Rua do Terreiro do Trigo, Lisboa

Miguel Martins de Sousa / José Pedro Henriques / Vanessa Galiza Filipe

1787 Cachimbos de Barro Caulínitico da Sé da Cidade Velha (República de Cabo Verde)

Rodrigo Banha da Silva / João Pimenta / Clementino Amaro

1801 Algumas considerações sobre espólio não cerâmico recuperado no Largo de Jesus (Lisboa) Carlos Boavida

1815 Adereços de vidro, dos séculos XVI-XVIII, procedentes do antigo Convento de Santana de Lisboa (anéis, braceletes e contas)

Joana Gonçalves / Rosa Varela Gomes / Mário Varela Gomes

1837 Da ostentação, luxo e poder à simplicidade do uso quotidiano: arqueologia e simbologia de joias e adornos da Idade Moderna Portuguesa Jéssica Iglésias

1849 Os amuletos em Portugal - dos objetos às superstições: o coral vermelho Alexandra Vieira

1865 Cerâmicas de Vila Franca de Xira nos séculos XV e XVI Eva Pires

1879 «Não passa por teu o que me pertence». Marcas de individualização associadas a faianças do Convento de Nossa Senhora de Aracoeli, Alcácer do Sal Catarina Parreira / Íris Fragoso / Miguel Martins de Sousa

1891 Cerâmica de Leiria: alguns focos de produção

Jaqueline Pereira / André Donas-Botto

1901 Os Fornos na Rua da Biquinha, em Óbidos Hugo Silva / Filipe Oliveira

1909 A casa de Pêro Fernandes, contador dos contos de D. Manuel I: o sítio arqueológico da Silha do Alferes, Seixal (século XVI) Mariana Nunes Ferreira

1921 O Alto da Vigia (Sintra) e a vigilância e defesa da costa Alexandre Gonçalves / Sandra Santos

1937 O contexto da torre sineira da Igreja de Santa Maria de Loures Paulo Calaveira / Martim Lopes

1949 A Necrópole do Hospital Militar do Castelo de São Jorge e as práticas funerárias na Lisboa de Época Moderna Susana Henriques / Liliana Matias de Carvalho / Ana Amarante / Sofia N. Wasterlain

1963 SAND - Sarilhos Grandes Entre dois Mundos: o adro da Igreja e a Paleobiologia dos ossos humanos recuperados

Paula Alves Pereira / Roger Lee Jesus / Bruno M. Magalhães

1975 Expansão urbana da vila de Cascais no século XVII e XVIII: a intervenção arqueológica na Rua da Vitória no 15 a 17

Tiago Pereira / Vanessa Filipe

1987 Novos dados para o conhecimento do Urbanismo de Faro em época Moderna Ana Rosa 
1995 Um exemplo de Arqueologia Urbana em Alcoutim: o Antigo Edifício dos CTT Marco Fernandes / Marta Dias / Alexandra Gradim / Virgílio Lopes / Susana Gómez Martínez

2007 Palácio dos Ferrazes (Rua das Flores/Rua da Vitória, Porto): a cocheira de Domingos Oliveira Maia

Francisco Raimundo

2021 As muitas vidas de um edifício urbano: História, Arqueologia e Antropologia no antigo Recreatório Paroquial de Penafiel Helena Bernardo / Jorge Sampaio / Marta Borges

2035 O convento de Nossa Senhora da Esperança de Ponta Delgada: o contributo da arqueologia para o conhecimento de um monumento identitário João Gonçalves Araújo / N’Zinga Oliveira

2047 Arqueologia na ilha do Corvo... em busca da capela de Nossa Senhora do Rosário Tânia Manuel Casimiro / José Luís Neto / Luís Borges / Pedro Parreira

2059 Perdidos à vista da Costa. Trabalhos arqueológicos subaquáticos na Barra do Tejo Jorge Freire / José Bettencourt / Augusto Salgado

2071 Arqueologia marítima em Cabo Verde: enquadramento e primeiros resultados do projecto CONCHA

José Bettencourt / Adilson Dias / Carlos Lima / Christelle Chouzenoux / Cristóvão Fonseca / Dúnia Pereira / Gonçalo Lopes / Inês Coelho / Jaylson Monteiro / José Lima / Maria Eugénia Alves / Patrícia Carvalho / Tiago Silva

2085 Trabalhos arqueológicos na Cidade Velha (Ribeira Grande de Santiago, Cabo Verde): reflexões sobre um projecto de investigação e divulgação patrimonial André Teixeira / Jaylson Monteiro / Mariana Mateus / Nireide Tavares / Cristovão Fonseca / Gonçalo C. Lopes / Joana Bento Torres / Dúnia Pereira / André Bargão / Aurélie Mayer / Bruno Zélie / Carlos Lima / Christelle Chouzenoux / Inês Henriques / Inês Pinto Coelho / José Lima / Patrícia Carvalho / Tiago Silva

2103 A antiga fortificação de Quelba / Khor Kalba (E.A.U.). Resultados de quatro campanhas de escavações, problemáticas e perspectivas futuras Rui Carita / Rosa Varela Gomes / Mário Varela Gomes / Kamyar Kamyad

2123 Colónias para homens novos: arqueologia da colonização agrária fascista no noroeste ibérico Xurxo Ayán Vila / José Mạ . Señorán Martín 


\title{
ARQUEOLOGIA NA ILHA DO CORVO... EM BUSCA DA CAPELA DE NOSSA SENHORA DO ROSÁRIO
}

Tânia Manuel Casimiro ${ }^{1}$, José Luís Neto² ${ }^{2}$ Luís Borges $^{3}$, Pedro Parreira ${ }^{4}$

\begin{abstract}
RESUMO
Entre 2014 e 2018 efectuaram-se quatro missões de arqueologia na ilha do Corvo, no arquipélago dos Açores, procurando promover a ligação entre a história, a arqueologia e a comunidade local. O objectivo principal era a descoberta de vestígios da primitiva capela de Nossa Senhora do Rosário, primeiro templo da ilha, fundado nos finais do século XVI, entretanto desaparecido. Ainda que a existência da dita capela não tenha sido confirmada foram produzidos novos contributos para o estudo da realidade insular de uma ilha periférica, mas intrinsecamente ligada às grandes rotas transatlânticas da Época Moderna. A cultura material identificada permitiu gerar conclusões sobre a ocupação daquele território entre o século XVI e o século XX sobretudo a nível do consumo doméstico, tipo de alimentação e economia.
\end{abstract}

Palavras-chave: Arqueologia Moderna, Arqueologia nos Açores, Ilha do Corvo

\begin{abstract}
From 2014 to 2018, four archaeological expeditions took place in Corvo island, on the Azorean archipelago, seeking to encourage stronger relationships between its local historical and archaeological heritage, and the local community. The main goal of these campaigns was to locate the remains of the Nossa Senhora do Rosário chapel, the first religious temple of the island built on the late sixteenth century. The excavations did not permit the identification of the chapel, however provided new contributions towards the study of the everyday life of that small island, located on the periphery of the European world, though connected to the great transatlantic routes of the Modern Age. The material culture provided new evidence regarding the human occupation of that territory, between the $16^{\text {th }}$ and the $20^{\text {th }}$ century, concerning domestic activities, food consumption and economic realities.
\end{abstract}

Keywords: Early Modern Archaeology, Archaeology in Azores, Corvo island.

\section{INTRODUÇÃO}

Apesar da ilha do Corvo deter as referências a investigações de cariz arqueológico mais antigas nos Açores (Podolijn, 1778); (Agostinho, 1946), só em 1964 estudiosos alemães aí procuraram indícios arqueológicos que se relacionassem com a origem do povoamento, todavia não foram identificadas evidências que conseguissem suportar qualquer conclusão (Medeiros, 1987: 48). Alguns anos depois, em
1982, arqueólogos americanos desenvolveram nova prospecção seguidos, em 1983, por Benedikt Isserlin (1984). Em 1986, Isserlin voltou à ilha, para a realização de uma campanha de quatro sondagens na vila, com o objectivo de procurar provas arqueológicas que documentassem uma ocupação pré-portuguesa, sem sucesso. Em Agosto de 2010, Nuno Ribeiro e Anabela Joaquinito fizeram uma visita ao Corvo tendo alegadamente descoberto estruturas-abrigo que poderiam, segundo os mesmos (Ribeiro et al.,

\footnotetext{
1. IHC/IAP - FCSH, Universidade Nova de Lisboa; tmcasimiro@fcsh.unl.pt

2. Direção Regional da Cultura do Governo Regional dos Açores; jose.lp.neto@azores.gov.pt

3. Direção Regional da Cultura do Governo Regional dos Açores; luis.cs.borges@azores.gov.pt

4. Direção Regional da Cultura do Governo Regional dos Açores; pedro.tc.parreira@azores.gov.pt
} 
2011), ser eventualmente pré-portuguesas, mas evidências científicas que conseguissem comprovar tal teoria nunca foram apresentadas (Figura 1).

A presente equipa signatária foi responsável por quatro campanhas arqueológicas, terrestres e subaquáticas, entre 2014 e 2018. Um dos objectivos principais passava pela localização da capela de Nossa Senhora do Rosário, primeiro templo da ilha do Corvo documentalmente registado, abandonado em 1690. A tradição local aponta a sua localização para uma casa que ali se encontra, conhecida como a casa de João Dias, local onde foram efectuadas duas sondagens em 2014. A comprovação que aquele não era o local da ermida levou a equipa a abrir uma sondagem numa das ruas da vila em 2015, bem como diversas sondagens em locais diversos em 2018. O local certo da ermida contínua, à data deste trabalho, por identificar (Figura 2).

\section{CAPELA DE NOSSA SENHORA DO ROSÁRIO}

A primeira referência à capela de Nossa Senhora do Rosário remonta ao século XVI, e mais concretamente a Gaspar Frutuoso, que se lamenta do facto de muitas crianças, filhas de escravos negros e de mulatos, que então constituíam a maioria da população no Corvo, poderem morrer sem baptismo: "Dizem que é anexa a igreja [Capela de Nossa Senhora do Rosário] à freguesia da Ponta Delgada da ilha das Flores, que será de trinta vizinhos, cujo vigairo, por causa os vai confessar cada Quaresma, algumas das quais, e muito tempo adiante, ficarão por confessar não podendo ir lá o vigairo, por causa da tromenta, e pelo mesmo caso estão as criaturas pagãs sete, oito meses até à vinda do sacerdote que as baptiza; o qual também às vezes não pode tornar tão cedo, por causa dos tempos rijos e dos ruins portos, assi do ilhéu, como da ilha das Flores, em que não se pode entrar e sair senão com mar manso." (Frutuoso, 1985: 136). A capela havia sido construída por volta de 1570 a 1580 por Gonçalo da Fonseca, descendente do donatário João da Fonseca ${ }^{5}$.

A situação eclesiástica mudou em finais de Quinhentos, sendo destacado um sacerdote permanente para a ilha do Corvo. Um desses sacerdotes, posterior-

5. Natural de Évora, recebeu as duas ilhas em 1504, tendo iniciado o seu povoamento pela ilha das Flores entre $1508 \mathrm{e}$ 1510 (Bragaglia: 2009, 22-23). mente pároco de Santa Cruz das Flores por trinta anos, o Padre Inácio Coelho, foi o padroeiro da construção do convento franciscano de São Boaventura, nas Flores, tendo igualmente patrocinado, do seu pecúlio, a reedificação "da igreja de Santa Cruz, e as ermidas de Santa Catarina, São Pedro e de São Sebastião, na ilha das Flores, as quais haviam sido queimadas pelos ingleses e estiveram cobertas de palha durante cerca de 40 anos, e ainda a de Nossa Senhora do Rosário, na ilha do Corvo" (Amaral: 1992, 123), em cerca de 1642. É natural que durante essa campanha de obras, a capela de Nossa Senhora do Rosário tenha adquirido uma traça arquitectónica da época e tenha sido, igualmente, telhada.

Seja como fôr, pouco mais de quarenta anos volvidos, a capela acabaria por ser fechada e o culto transitou para a actual igreja matriz de Nossa Senhora dos Milagres, inaugurada em 169o, tendo sido iniciada a sua construção cinco anos antes. As razões que a isso levaram são narradas pelo antigo sacerdote corvino, o Padre Lourenço Jorge: "Pelos livros $d a$ "Arca", e principalmente pelos das Visitas se pode saber o que era a primeira igreja do Corvo. Foi erigida a ermida por Gonçalo da Fonseca "para paróquia de seus escravos e vassalos" sobre a "rocha frágil e quebradiça" do Porto do Rosário, actual Porto da Casa, à direita da ladeira que dá acesso às casas. Não comportava mais que a terça parte do povo, assistindo a maior parte no adro aos oficios divinos. A sua porta não tinha chave e permanecia aberta dia e de noite. O primeiro visitador manda ao Vigário que, no mais breve tempo que lhe seja possível, mande, à custa da Fábrica Pequena, pôr uma fechadura com sua boa chave na porta travessa com que a mandará fechar e estar fechada, sendo a outra trancada por dentro; e recolherá a dita chave à sua mão, onde a poderão procurar os devotos que quiserem fazer oração. Avisa o Vigário que "por nenhuma maneira consinta que pessoa alguma da freguesia ou fora dela, coma, beba, cante, baile ou durma na igreja, por mais que lho peçam"! "A Tumba sempre esteve no adro, posta no chão, maltratada de chuvas e calmas, por ser pequena a igreja". Para obviar a esta inconveniência, mas não querendo sobrecarregar com gastos a Fábrica da igreja, manda que o mordomo da Fábrica Pequena, faça meter na parede da igreja, pela banda de dentro, defronte da pia baptismal, do meio para o alto, dois barrotes a par, sobre os quais se porá a dita tumba, para melhor resguardo seu, sem que impeça estar por baixo bancos em que se assentem. $O$ adro 
franqueado sempre aos "animais que vagueavam pelos caminhos" por cuja causa foi encarregada a Fábrica Pequena de mandar fechá-lo com uma cancela dentro do prazo de dois meses a contar da terceira publicação da "Visita", sob pena de 500 réis para a bula e meirinho.

Não era um edificio robusto. O pavimento de terra, coberto de junco. Ao lado da porta, uma tosca pia de pedra para baptismos. Um pouco mais acima uma "imagem do Santo Cristo à coluna, posta em um caixão pouco decente", colocado no chão. Uma escada dava acesso ao púlpito. O retábulo era constituído por "um pano cuja cor primitiva se ignora e que se não sabe se é de linho ou lã", cobrindo a parede do fundo. Em um pequeno nicho, colocado a meio, estava a "veneranda imagem, e tão milagrosa da Senhora do Rosário, em tal estado que não há nela mais que uma cabilla (sic) e algumas roupas, sem braços, $e$ o Menino que neles havia de sustentar, com a mesma deformidade". "A pedra do altar quebrada", o frontal "no mesmo estado" do pano-retábulo; "quatro castiçais de pau, muito indecentes"; "um cálice com o pé quebrado" e "um missal mui antigo, mui roto e mui pequeno, em muitas partes escrito e remendado, de modo que é preciso adivinhar para se dizer a missa"! Durante a segunda Visita manda-se "ao Feitor do Senhor Conde que mande fazer um armário à parte direita do altar, com duas portas, bem feito e capaz para se recolherem os ditos ornamentos, o que assim cumprirá sob pena de $2 \$$ ooo réis que pagará de sua fazenda", nunca se fazendo menção à sacristia, que certamente não existia. Os paramentos eram "de sarja e lã e muito usados e não os há de todas as cores litúrgicas". Uma "custódia de pau, limitada a não ter sequer um círculo de prata" nem pintura alguma; "umas galhetas de estanho"; "um Batistério podre e em muitas partes falto de folhas". Foi esta a descrição da igreja do Corvo em 1684. [...]

O terceiro visitador João Garcia Dutra foi o primeiro que tratou da construção de outra igreja em lugar mais amplo e seguro, pois que a rocha onde assentava a igreja se ia arruinando a respeito dos "baques do mar" "e "o sítio era incapaz de se alargar". (Jorge, 2001: 205-207).

\section{AS CAMPANHAS ARQUEOLÓGICAS}

As campanhas arqueológicas foram efectuadas por uma equipa da Direcção Regional da Cultura dos Açores e Museu de Angra do Heroísmo. O trabalho assentou em ações de prospeção, pesquisa documental e realização de sondagens arqueológicas conforme determinado pela Direção Regional da Cultura, no âmbito das atribuições e incumbências definidas no Decreto Legislativo Regional n.. $27 / 2004 / A$, de 24 de agosto e no Decreto Regulamentar Regional n.. $8 / 2013 / A$, de 17 de junho.

$\mathrm{Na}$ campanha de 2014 foram efectuadas duas sondagens na Casa de João Dias, que corresponde a um lote de terreno de habitação sobranceiro à escarpa Sudeste da Rua do Porto da Casa, sem número de polícia, tal como acontece com todas as casas da vila. A casa está desocupada, devido à mudança da proprietária para a ilha do Pico. O lote apresenta uma forma retangular, orientado Nascente-Poente, com as portas e janelas viradas a Sul, obtendo assim maior exposição solar. O edifício apresenta uma forma paralelepipédica, com dois pisos de pequena altura (1,90 metros de pé-direito), telhado de duas águas, sustentado numa estrutura simples de madeira. O piso térreo apresenta, de Poente para Nascente, uma cozinha com forno (divisão A), uma sala retangular comprida (divisão B), uma casa-de-banho com banheira, lavatório e retrete (divisão C), um pequeno alpendre no vão da escadaria exterior de acesso ao primeiro piso (divisão D) e uma sala de arrumos (divisão E) (Figura 3).

Faz-se notar que, apesar da casa se integrar claramente na tipologia tradicional da habitação corvina (Caldas, 2001, 23-26), a habitação foi sofrendo alterações claras à estrutura primitiva. A inclusão do forno na estrutura habitacional, realizada com blocos de cimento, à vista, é demonstrativa da sua contemporaneidade; a supressão da finalidade original da divisão $B$, que era a de albergar animais domésticos (loja), a inclusão da casa-de-banho (divisão C) na mesma divisão $B$, que a corta de toda a sua extensão primeva, são disso mesmo testemunhos exemplares. Toda a área não coberta foi pavimentada com uma calçada de seixos rolados, que, entretanto, em muitas áreas, foi substituída por cimento. Aliás, os currais e outros edifícios de apoio foram desactivados e substituídos por um único, de tijolo de cimento, também ele actualmente desactivado.

O material de construção das paredes é a pedra vulcânica local, ligada por terra, rebocado com terra e cal e caiado. $\mathrm{O}$ acesso aos quartos é feito pelo exterior, por escadaria de pedra.

A sondagem 1 tinha 2 × 3 metros, tendo sido implantada no extremo Nordeste da sala B. Após a limpe- 
za dos detritos ali acumulados, apresentou um piso de cimento (piso 1) que, após ser levantado, revelou uma camada de terra castanha avermelhada, argilosa, compacta (camada 1), camada essa que se prolongou até aos $60 \mathrm{~cm}$ de profundidade, onde se revelou totalmente estéril. Sensivelmente a meio do lado Sul, a partir dos $30 \mathrm{~cm}$ de profundidade, apresentou algumas pedras aglomeradas, que depois de limpas, revelaram tratar-se de um simples amontoado criado para deixar outras áreas mais transitáveis. Acresce o baixíssimo grau de exumação de materiais, bem como a sua natureza, aliada à do próprio solo, que nos levaram a concluir tratar-se simplesmente de solo agrícola. De referir que, no canto Noroeste, detetámos uma bolsa semicircular, de terra castanha escura, correspondente a uma fossa de detritos da Casa de João Dias (camada 2). A sondagem 2 correspondeu a toda a divisão D. Após a limpeza dos detritos ali acumulados, detetou-se um piso de seixos rolados (piso 1) que ocupou a metade Este da sondagem. Prosseguindo a escavação na metade Poente, detetámos uma camada uniforme de bagacina (camada 1) até $30 \mathrm{~cm}$ de profundidade, onde constatámos estar perante uma outra fossa, ainda activa, pelo que se suspendeu a escavação (Figura 4).

Entre os dias 18 a 31 de Agosto de 2015 foi realizada a segunda campanha arqueológica terrestre e a primeira marítima. O objectivo da segunda campanha terrestre foi igualmente a identificação da ermida de Nossa Senhora do Rosário. Nesse sentido e atendendo que os resultados do ano anterior tinham demonstrado que a ermida não se localizava na Casa de João Dias, foi aberta uma sondagem na Rua do Porto da Casa, no exterior da Casa de Maria João. A escolha do local recaiu nas proximidades de um edifício com uma arquitectura particular e destacável, que pode ter correspondido à de uma igreja (Figura 5).

A sondagem tinha $2,5 \mathrm{X}_{3}$ metros, orientada Norte-Sul, sendo executada na via pública, com vista a detectar o eventual adro do antigo templo. A camada 1 tratava-se de um piso que era constituído por cimento, sendo removido com o auxílio de um martelo pneumático. Sob este, apareceu um outro piso, constituído por seixos de dimensões variáveis, somente preservado na metade Poente da sondagem, uma vez que, na metade Este, a terra encontrava-se revolvida para instalação de tubagens muito recentes. A partir de então recorreu-se unicamente a escavação manual. Removido este piso, defrontámo-nos com uma camada de terra castanha escura, muito argilosa, que, ao ser metodicamente removida, mostrou, de perfil, uma estrutura de canalização arcaica feita de seixos rolados. Os materiais exumados pertencem, inequivocamente, ao século XX (Figura 6). Mais abaixo surgiu uma outra camada, possível de datar entre os séculos XVI e XVIII. Esse contexto, que se anuncia pela materialidade cerâmica, é coevo com a ocupação que se pretendia localizar, a capela de Nossa Senhora do Rosário. A escavação teve de ser interrompida a cerca de, sensivelmente, 120 $\mathrm{cm}$ de profundidade, porquanto foi inundada pelo conteúdo de uma fossa séptica localizada a Norte da sondagem, impedindo que se chegasse aos níveis estratigráficos pretendidos. Com celeridade, depois de se constatar que não se tratava de uma fuga da rede pública, ponderadas as razões de saúde pública, procedeu-se, em conformidade com o parecer da autarquia, fazendo-se o recobrimento imediato da sondagem (Figura 7 ).

A terceira campanha, exclusivamente subaquática, teve lugar em 2016.

Entre os dias 7 e 18 de Maio de 2018, decorreu a quarta campanha, motivada pela intenção de se avançar com obras de reabilitação no espaço privado, interior, que não fora escavado em 2015, no imóvel na Rua do Porto da Casa, conhecido como a Casa de Maria João. Atendendo aos resultados aí obtidos, alargou-se as sondagens à Casa de Luís Pacheco e ao quintal da Casa de Paula Dias.

Na primeira casa foi aberta uma sondagem, de $2 \mathrm{x} 2$ metros, na zona da loja, com vista a detectar o eventual corpo do templo. Devido à exiguidade do espaço, em sondagem correspondeu a cerca de $40 \%$ da loja. O piso 1 era composto por um pavimento de seixos rolados e que, à data dos trabalhos arqueológicos, se encontrava coberto por uma camada de palha. Imediatamente abaixo, a camada 1 era composta por terra homogénea, castanho avermelhada, compacta, com presença de numerosas pedras vulcânicas de diversos calibres. Da camada I foram recolhidos 11 fragmentos de cerâmica de cronologias atribuíveis aos séculos XIX e XX. Rapidamente se alcançou o substrato geológico, estando este, em média, a cerca de $90 \mathrm{~cm}$ de profundidade, não se encontrando evidências de quaisquer estruturas arqueológicas. Foi decidido alargar a sondagem junto à parede Sul da divisão, de modo a procurar fósseis diretores na vala de fundação das paredes, que pudessem indicar uma datação para a construção do imóvel, algo que se revelou infrutífero (Figura 8). 
Num pequeno espaço de horta de cultivo, no quintal da Casa de Maria João, foi aberta a sondagem 2 com 2 x 1 metros, com vista a, com a sondagem no tardoz, excluir definitivamente a hipótese de ali ter sido a capela. A camada 1 apresentava uma coloração castanha escura, pouco compacta, correspondendo à terra arada da horta em uso. A camada 2, apresentava sedimento homogéneo, castanho escuro, com muita incidência de pedras de grande e médio calibre. Apenas alguns vestígios de fauna foram encontrados nesta sondagem. Há que salientar a presença de uma pia, em pedra, encastrada no muro do quintal, que terá servido para alimentação de suínos e/ ou aves de capoeira.

Após, e com a autorização e incentivo dos moradores da vila, e especificamente dos do Porto da Casa, prosseguiu a iniciativa de se efectuarem mais sondagens de verificação do espaço, naquela área.

A sondagem 3 foi aberta na Casa de Luís Pacheco. Devido à exiguidade do espaço, esta foi aberta do lado interior da parede Sul da casa, com uma dimensão de 2 x 1 metros. O piso 1 , de cor esbranquiçada, era muito compacto e composto por detritos quotidianos do uso doméstico. Sob o piso 1, e cortando longitudinalmente a sondagem a meio, foi detetado o muro 1, de pedra seca, de médio a grande calibre. A Nascente do muro 1 foram identificadas duas camadas. A camada 1 apresentava coloração cinza escuro, pouco compacta e com pedras soltas de médio e pequeno calibre, de onde foram retirados materiais arqueológicos; a camada 2, homogénea, de cor castanho avermelhada, extremamente compacta a cerca de 1,20 metros de profundidade. A Poente do muro 1, a sondagem apresentava outra estratigrafia, sob o piso 1, camada 3, de terra castanho avermelhada pouco compacta e camada 4 , de cerca de $5 \mathrm{~cm}$ de espessura, de carvões; continuidade da camada 2, homogénea, de terra castanho avermelhada extremamente compacta.

As sondagens 4 e 5 foram abertas no quintal da Casa de Paula Dias. Do lado Norte da pequena baía do Porto da Casa, a Nascente do Canto do Porto da Casa, e separado deste por um barranco, destacavam-se os vestígios de uma construção com cunhais em cantaria. O interior dessa estrutura encontra-se entulhado e suporta uma pequena piscina. Optou-se por abrir duas sondagens no exterior, a Sul, da estrutura. A sondagem 1, de 2 x 1 e a sondagem 2, de 1 x 1 metros. $\mathrm{Na}$ sondagem 1, destacavam-se duas camadas. A camada 1 de terra castanha, pouco compacta, e a cama- da 2, de terra castanha, compacta, com incidência de seixos de pequeno calibre. Nesta sondagem não foram encontrados quaisquer artefactos. A sondagem 2 apresentava as mesmas camadas da sondagem 1, excepção feita ao facto de terem sido recolhidos fragmentos de cerâmicas dos séculos XIX e XX.

\section{CULTURA MATERIAL}

Na intervenção de 2014, na Casa de João Dias, as recolhas materiais efectuadas na camada 2, da sondagem 1 , bem como da camada 1, da sondagem 2 levam-nos a concluir que a construção da Casa de João Dias ocorreu em finais do século XVIII, não se tratando do edifício do primeiro templo da ilha. Anteriormente a esta casa, este espaço, mercê de se encontrar alcandorado sobre a falésia, terá sido somente um campo agrícola. E esse campo agrícola, como é comum nos campos agrícolas, foi sendo adubado com os sobejos da casa de quem o cultivava. Assim se explicam os poucos materiais encontrados, de cronologias demasiado longas, referentes aos anteriores séculos de ocupação. Algumas delas, independentemente do seu estado muito fragmentário, oferecem uma datação precisa. Estes fragmentos, se bem que pouco numerosos, são evidentes indicadores que o local apenas foi urbanizado, pela primeira vez, com a construção da Casa de João Dias e asseguram que não foi este o local da construção da capela de Nossa Senhora do Rosário, abandonada em 1690.

Os materiais exumados da sondagem 1, camada 1 , apresentam-se muitíssimo fragmentados e quebradiços, podendo ser divididos em dois grupos distintos, com o primeiro a compreender materiais orgânicos, que correspondem a fragmentos ósseos. Há diversos fragmentos de ossos, e dentes de ruminante, nomeadamente um chifre de pequeno ruminante carbonizado. Existe um fragmento de costela de coelho, diversos fragmentos de espinhas de um mesmo peixe, um fragmento de crânio de roedor, bem como duas costelas, um fémur e uma tíbia de morcego. $\mathrm{O}$ segundo grupo corresponde a inorgânicos, no caso materiais cerâmicos e um pétreo. Os cerâmicos são de construção e de uso comum. Do primeiro tipo existem trinta fragmentos de telha mourisca, muito provavelmente das Flores, que é o centro produtor mais próximo (Fernandes, 1993; 2001), tendo lá sido registado um forno de telha (Neto et al., 2014). De uso comum foram exumados dois fragmentos, de pastas claras, compactas, com a inclusão de alguns 
elementos não plásticos. Um é esmaltado a branco e recebeu engobe transparente e o outro é vidrado a melado. Pelas características da pasta, do engobe e do vidrado, correspondem a exemplares das produções da região de Sevilha, enquadráveis no século XVI (Sousa, 2012) (Figura 9).

Existem dois fragmentos de faianças portuguesas, a azul e branco, feitas a partir de pastas claras, sugerindo produções de Lisboa. Correspondem a um fragmento de bordo de um prato, decorado com círculos concêntricos na aba, datável entre 1660 e 1720, apresentando um furo, indicando uma possível reparação (Casimiro, 2013). Surgiu também um fragmento de cerâmica de pastas vermelhas. O acabamento interno demonstra vestígios de aplicação de vidrado melado. Pelas características da pasta e do vidrado, corresponde a um exemplar das produções da região de Lisboa enquadrável nos séculos XVII a XVIII (Casimiro, et al., 2018).

Há igualmente louças comuns de pastas vermelhas não vidradas. Deste tipo de cerâmicas existe um fragmento de bordo de alguidar, extrovertido, em aba pendente, um fragmento de taça, apresentando um bordo extrovertido, brunido na face interna e outros dois fragmentos. Pelas características das pastas e da aguada correspondem a produções regionais, muito provavelmente das Flores, centro produtor mais próximo (Andrade, 2014; Fernandes, 2001). As formas são genericamente enquadráveis entre os séculos XVI a XVIII.

Uma âncora de pedra foi identificada. Trata-se de um monólito quartzítico com um furo, que mede $42 \mathrm{~cm}$ de comprimento, tendo $26 \mathrm{~cm}$ de altura. O buraco, onde passava uma corda, apresentou $6 \mathrm{~cm}$ de diâmetro. Este tipo de âncora improvisada, para pequenas embarcações, ainda hoje está em uso.

Os materiais exumados na sondagem 2, camada 1, são exclusivamente materiais cerâmicos. Existem dois fragmentos de faianças portuguesas, a azul e branco, produção de Lisboa. Um fragmento de bordo de uma taça, esmaltado a branco e pintado a azul, com um círculo concêntrico, e um fragmento de prato. Pelas caraterísticas da pasta, do vidrado e da decoração, correspondem a exemplares enquadráveis no século XVIII.

De produção industrial, e já enquadráveis na segunda metade do século XIX, temos dois fragmentos de louça estampada. Um deles apresenta decoração com motivo de estátua, a verde, ostentando a marca da fábrica de louça de Sacavém, tendo sido produzi- do entre as décadas de sessenta a inícios de noventa do século XIX (Assunção, 1997). Dois fragmentos são integráveis nas produções da Fábrica de Loiça Terceirense, correspondendo a faianças com motivos decorativos florais, a azul, datando da década de 20 do século XX. Dois outros fragmentos, de faiança industrial, com decoração de "chinoiserie", a azul sobre branco, podem corresponder a uma produção exógena, mas a reduzida dimensão não permite mais assertiva classificação. Por fim, um outro fragmento de faiança, a azul sobre branco, de tipo geométrico e com a decoração em relevo, é genericamente enquadrável entre as décadas de 30 e 50 do século XX.

Na intervenção da Rua do Porto da Casa, em frente à Casa de Maria João, em 2015, foram identificados objectos que podem ser datados entre os séculos XVI e XX. Correspondem a cerâmica de construção, semelhante à identificada na Casa João Dias e a louça de uso doméstico. As produções possíveis de atribuir aos finais do século XIX e XX correspondem a louça branca ou estampada com paisagens. As cerâmicas regionais, nomeadamente os alguidares, podem ter sido utilizados durante mais de três séculos, sem permitirem uma cronologia mais detalhada. Ainda possíveis de datar do século XIX e XX, dois fragmentos de garrafas em grés, produzidas no Norte da Europa, que transportariam água ou genebra (Sequeira e Casimiro, 2015), e alguns fragmentos de garrafas de vidro verde. Os fragmentos possíveis de datar dos séculos XVI e XVII correspondem a faianças com decoração a azul, sobretudo pratos e taças, ou cerâmicas vidradas de produção lisboeta, com possibilidade de algumas produções andaluzas. Destacam-se alguns fragmentos a azul e branco, de possível produção holandesa.

Nas sondagens abertas em 2018 a maioria dos objectos corresponde a peças produzidas nos séculos XIX e XX, tais como cerâmicas regionais e produções industriais (Figura 10).

\section{CONCLUSÃO}

No ano de 2014, os indicadores estratigráficos das sondagens conjugados com os materiais exumados na Casa de João Dias foram suficientes para invalidarem a localização tradicional da Capela de Nossa Senhora do Rosário. A ausência de estruturas arquitectónicas na sondagem 1 , a escassez de cultura material e sua excessiva fragmentação, bem como os vestígios 
faunísticos de roedores e morcegos apontam coerentemente para a aludida interpretação do espaço, enquanto campo agrícola. $\mathrm{O}$ facto de existirem escassos elementos ósseos e cerâmicos que se relacionem com o quotidiano alimentar, não a coloca em causa, porquanto é comum que os restos alimentares fossem usados como fertilizante. Em meados do século XVIII, o terreno recebeu a sua primeira edificação que, apesar das remodelações, acrescentos e adaptações, continua a ser a mesma desde então até aos dias de hoje, pelo que é seguro afirmar que a Casa de João Dias foi construída por meados de Setecentos.

A procura da capela nos anos seguintes também não se revelou conclusiva. Na Rua do Porto da Casa, na Casa de Maria João, a interrupção da escavação antes de chegarmos às camadas mais antigas não deu acesso às camadas coevas à ocupação da ermida (no caso, do seu primitivo adro) pelo que não conseguimos chegar a nenhuma conclusão, em 2015, mas na intervenção de 2018, foram identificados locais ocupados durante os séculos XIX e XX, sem possibilidade de identificação da ermida em nenhum deles. A impossibilidade, até agora, de identificação positiva da capela não retira o interesse aos contextos arqueológicos identificados, mesmo que mais tardios do que aqueles que inicialmente procurámos. Através dessas realidades é possível concluir que os habitantes da ilha do Corvo, ainda que em quantidades mais moderadas, tinham acesso ao mesmo tipo de materialidades que os restantes habitantes dos Açores. A cerâmica de produção regional parece ser sobretudo utilizada na confecção de alimentos, enquanto o consumo de alimentos à mesa era, sobretudo, efectuado com louça importada de Portugal continental, maioritariamente de Lisboa. Um fragmento de prato holandês, passível de datar dos finais do século XVII, ou inícios do século XVIII, demonstra que poderiam existir habitantes com capacidade económica para a aquisição de peças importadas. Essa realidade parece ter-se mantido, desde o século XVII até ao XIX.

Não obstante a sua periférica localização, face à Europa, mas também no contexto do arquipélago dos Açores, a ilha do Corvo parece ter sido frequentemente abastecida pelos produtos em uso corrente, na época, ainda que certamente condicionada à sua realidade, reduzido tamanho da sua comunidade e constante presença de intempéries climatéricas, partilhando a sua gente identidade insular característica das ilhas.

\section{BIBLIOGRAFIA}

AGOSTINHO, José (1946) - Achados arqueológicos nos Açores. In Açoreana, Angra do Heroísmo: Boletim da Sociedade Afonso Chaves (separata, 11 páginas).

AMARAL, Maria Regina Amorim de Carvalho (1992) - O convento de São Boaventura em Santa Cruz das Flores. In Insulana. Vol. 48. Ponta Delgada: Instituto Cultural de Ponta Delgada. pp. 121-137.

ANDRADE, Alexandra (2014) - Cerâmica dos Açores. Ponta Delgada: Vice-Presidência do Governo, Emprego e Competitividade Empresarial - Centro Regional de Apoio ao Artesanato.

ASSUNÇÃO, Ana Paula (1997) - Fábrica de louça de Sacavém. Sintra: Inapa.

BRAGAGLIA, Pierluigi (2009) - Ilha das Flores. Açores. Roteiro histórico e pedestre. Fajã Grande, Flores: Edição de autor.

CALDAS, João Vieira (2001) - A casa do Corvo. In Inventário do Património Imóvel dos Açores - Vila Nova do Corvo. Angra do Heroísmo: Direção Regional da Cultura e Instituto Açoriano de Cultura. pp. 23-26.

CASIMIRO, Tânia Manuel (2013) - Faiança portuguesa: datação e evolução crono-estilística. In Revista Portuguesa de Arqueologia, volume 16. Lisboa: DGPC. pp. 351-367.

CASIMIRO, Tânia Manuel, HENRIQUES, José Pedro, FILIPE, Vanessa e BOAVIDA, Carlos (2018) - Lead glazed ceramics in Lisbon (16th-18th centuries). In GlazeArt 2018. Lisboa: LNEC. pp. 268-282.

FERNANDES, Isabel Maria (1993) - Cerâmica Açoriana. Catálogo. Barcelos: Museu de Olaria.

FERNANDES, Isabel Maria (2001) -“Cerâmica. In Enciclopédia Açoriana. Angra do Heroísmo: Direção Regional da Cultura, Centro de Conhecimento dos Açores. http:// www.culturacores.azores.gov.pt/ea/pesquisa/default. aspx?id=1615

FRUTUOSO, Gaspar (1985) - Saudades da Terra. Livro VI. Ponta Delgada: Instituto Cultural de Ponta Delgada.

ISSERLIN, B. S. J. (1984) - Did Carthaginian mariners reach the Island of Corvo (Azores)? Report on the results of the joint field investigations undertaken on Corvo in June 1983. in Rivista di Studi Fenici. Sommari del volume XII, 1. Roma: Fabrizio Serra Editore. pp. 31-46.

JORGE, Lourenço (2001) - Notas do Corvo. (Organização de João Saramago). Vila do Corvo: Câmara Municipal do Corvo.

MEDEIROS, Carlos Alberto (1987) - A ilha do Corvo. Lisboa: Livros Horizonte.

NETO, José Luís, BORGES, Luís e PERES, Magda (2014) Forno de cerâmica da Rua Padre Luís Pimentel Gomes. In Carta Arqueológica dos Açores. Portal Cultura Açores do Governo Regional dos Açores. Disponível em http://www. culturacores.azores.gov.pt/paa/ca/default.aspx 
PODOLIJN, Johan (1778) - Nagra anmarkningar om de Gamles sjofart, i anledning af nagra carthaginensiska och cyrenaiska mynt, fundne ar 1749, pa ena f de acoriska oarne. In Det Gotheborgska Wetenskaps och Witterhets Samhallets Handlingar. Goteborg. pp. 106-108.

RIBEIRO, Nuno, JOAQUINITO, Anabela, PEREIRA, Sérgio (2011) - Phoenicians in the Azores, myth or reality? In 15th Symposium on Mediterranean archaeology, Catania, Sicilia: Universitá di Catania.

SEQUEIRA, João e CASIMIRO, Tânia Manuel (2015) Fragmentos do mundo contemporâneo: objectos em grés recuperados no Tejo. In CIRA - Arqueologia, n. IV. Vila Franca de Xira: Museu Municipal da Câmara Municipal de Vila Franca de Xira. pp. 209-215.

SOUSA, Élvio (2012) - A importação de cerâmica europeia para os arquipélagos da Madeira e dos Açores no século XVI. In Velhos e Novos Mundos: Estudos de arqueologia moderna. Volume II. Lisboa: Centro de História Além-Mar, FCSH, Universidade Nova Lisboa. pp. 797-81o.

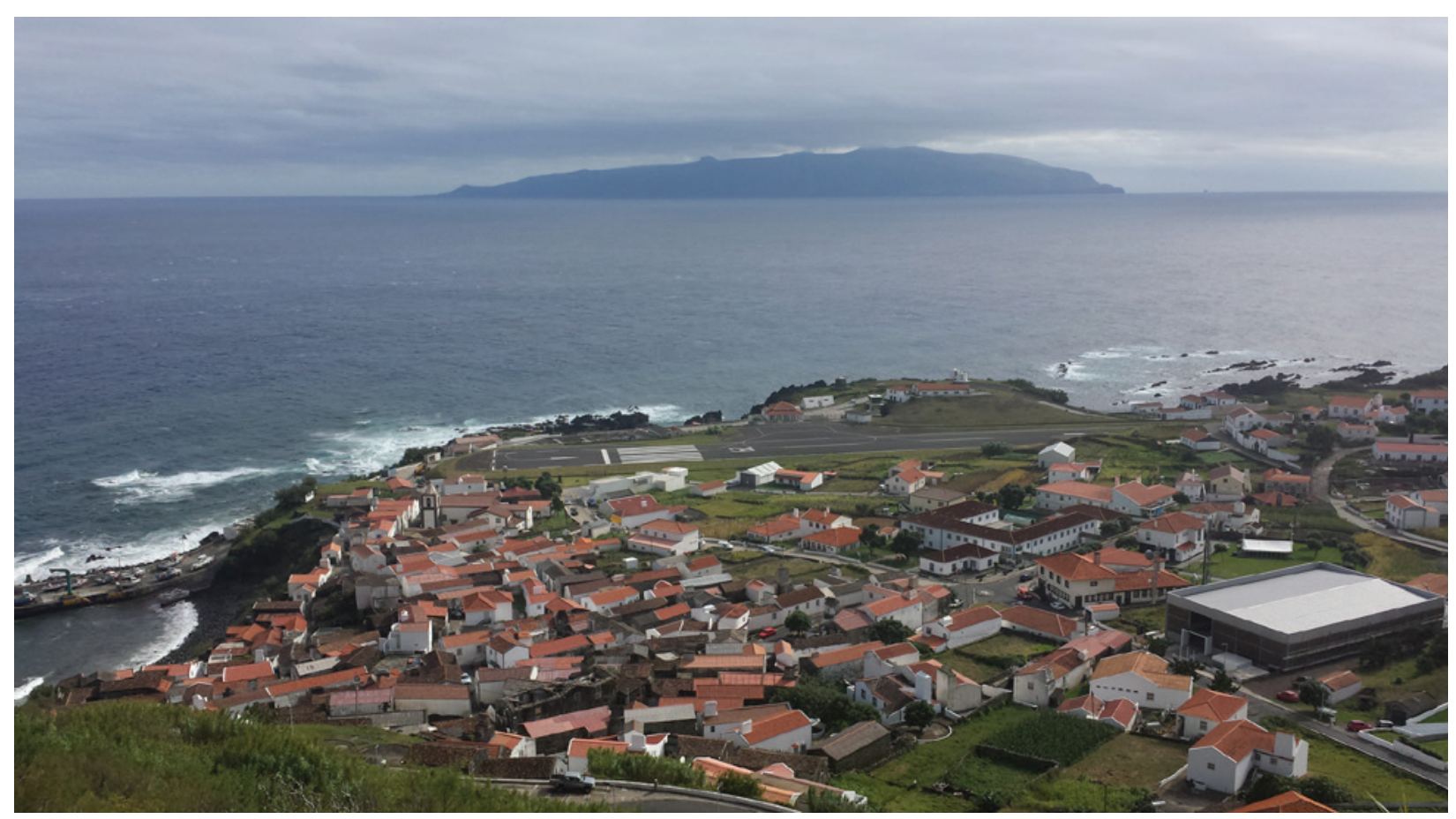

Figura 1 - Vista elevada da Vila do Corvo; Autor: Direção Regional da Cultura dos Açores. 


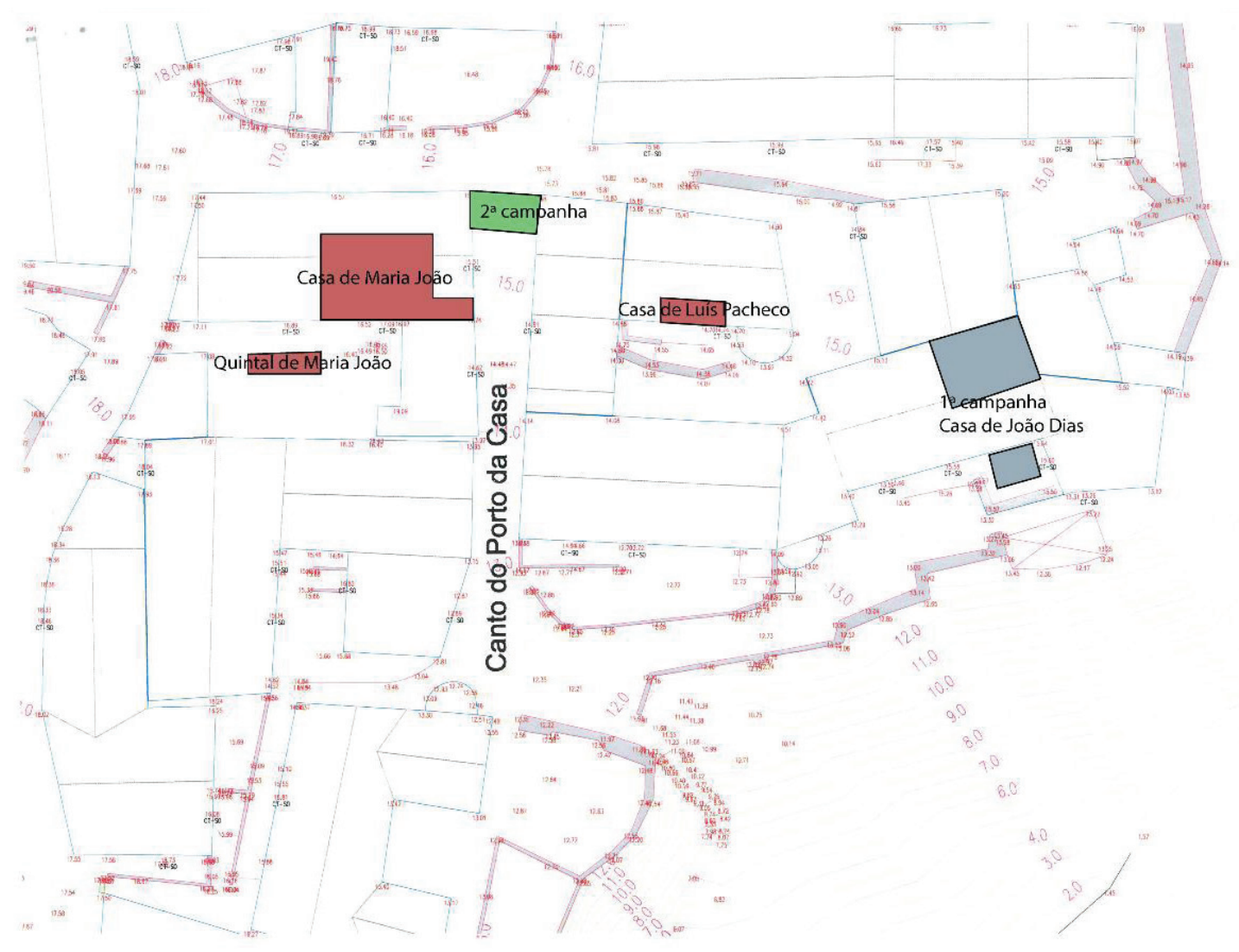

Figura 2 - Mapa da Vila do Corvo, com implantação das áreas intervencionadas; Autor: Luís Borges.

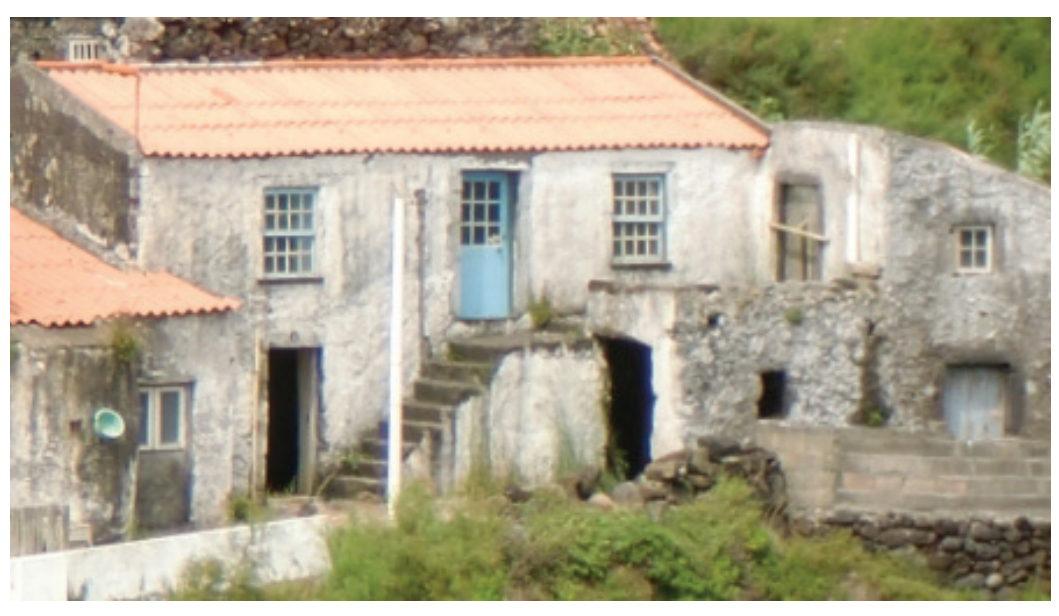

Figura 3 - A Casa de João Dias; Autor: Direção Regional da Cultura dos Açores. 
Alcado Nascinte

Comaden 1

Akado Norte

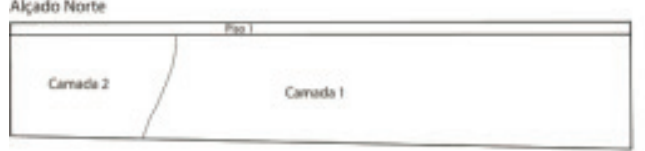

Alcado Poente

\begin{tabular}{|l|l|}
\hline Camata 1 & comade 2 \\
\hline
\end{tabular}

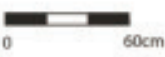

Cura de loba Dlas

Lils Borges / Magda Pere

11 de Agorto de 2014

Figura 4 - Cortes estratigráficos da intervenção na Casa de João Dias; Autor: Luís Borges e Magda Peres.

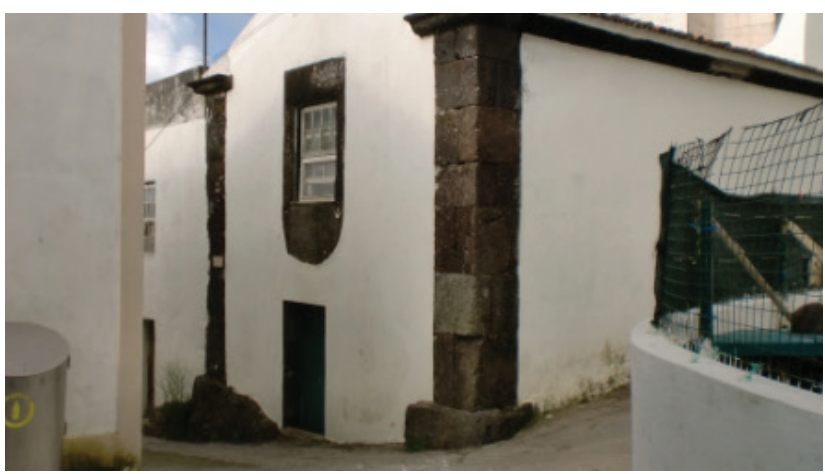

Figura 5 - A Casa de Maria João, na Rua do Porto da Casa; Autor: Direção Regional da Cultura dos Açores.

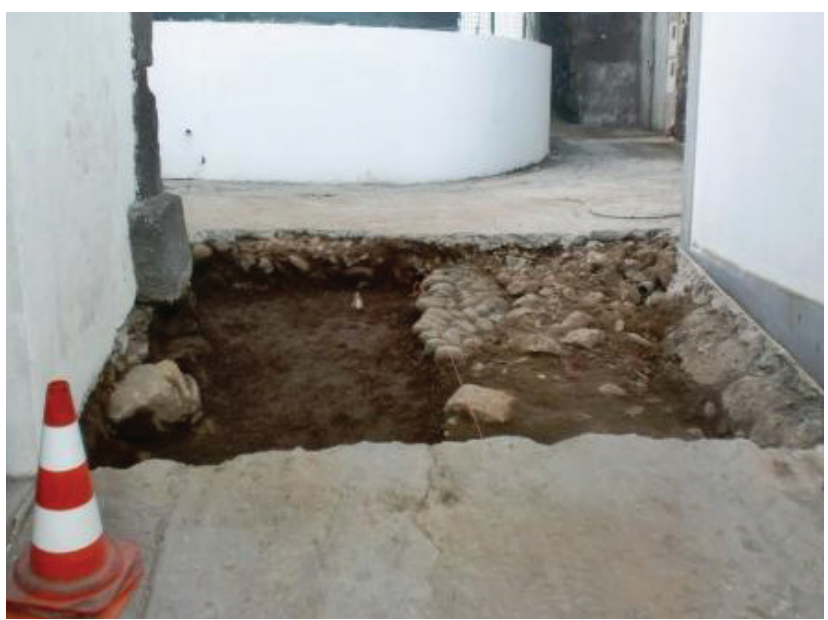

Figura 6 - Sondagem no exterior na Casa de Maria João; Direção Regional da Cultura dos Açores. 

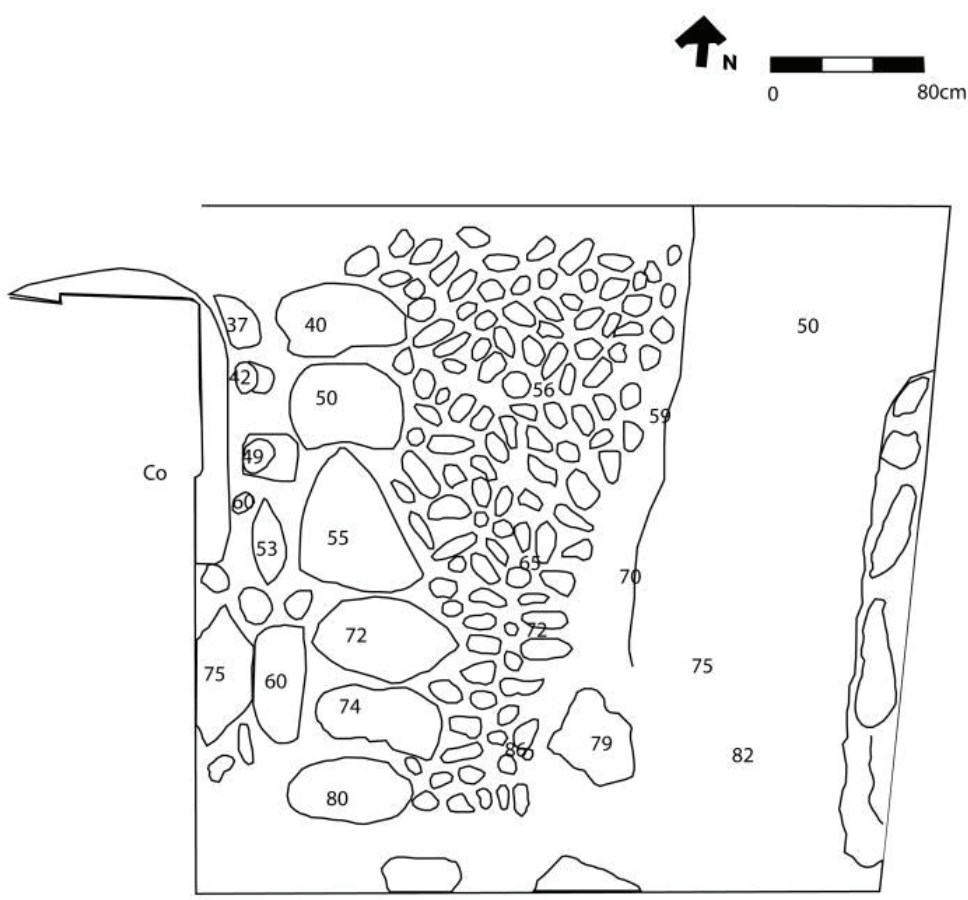

Sondagem 1

Porto da Casa - Vila do Crovo

22/08/2015

Desenho:J.L. Neto / P. Parreira / R. Borges

Tintagem:L. Borges

Figura 7 - Registo técnico de plano da sondagem no exterior da Casa de Maria João; Autor: José Luís Neto, Pedro Parreira e Luís Borges.

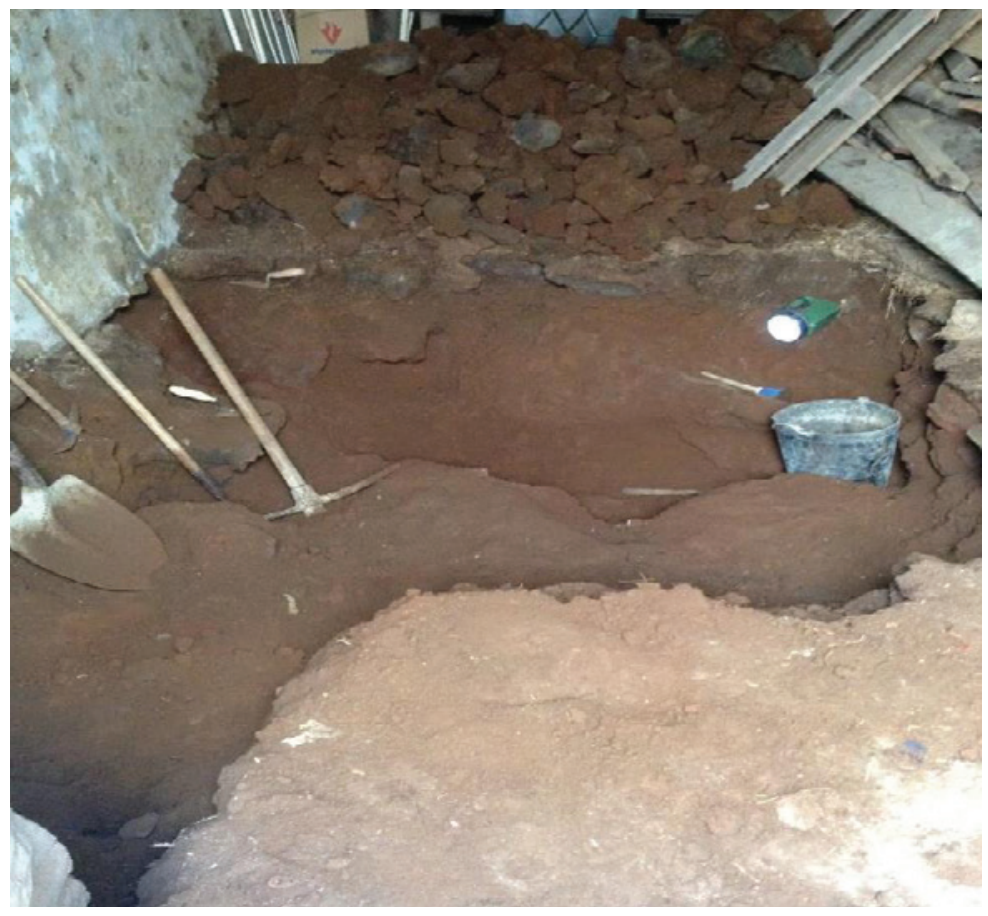

Figura 8 - Sondagem no interior da Casa de Maria João; Autor: Direção Regional da Cultura dos Açores. 

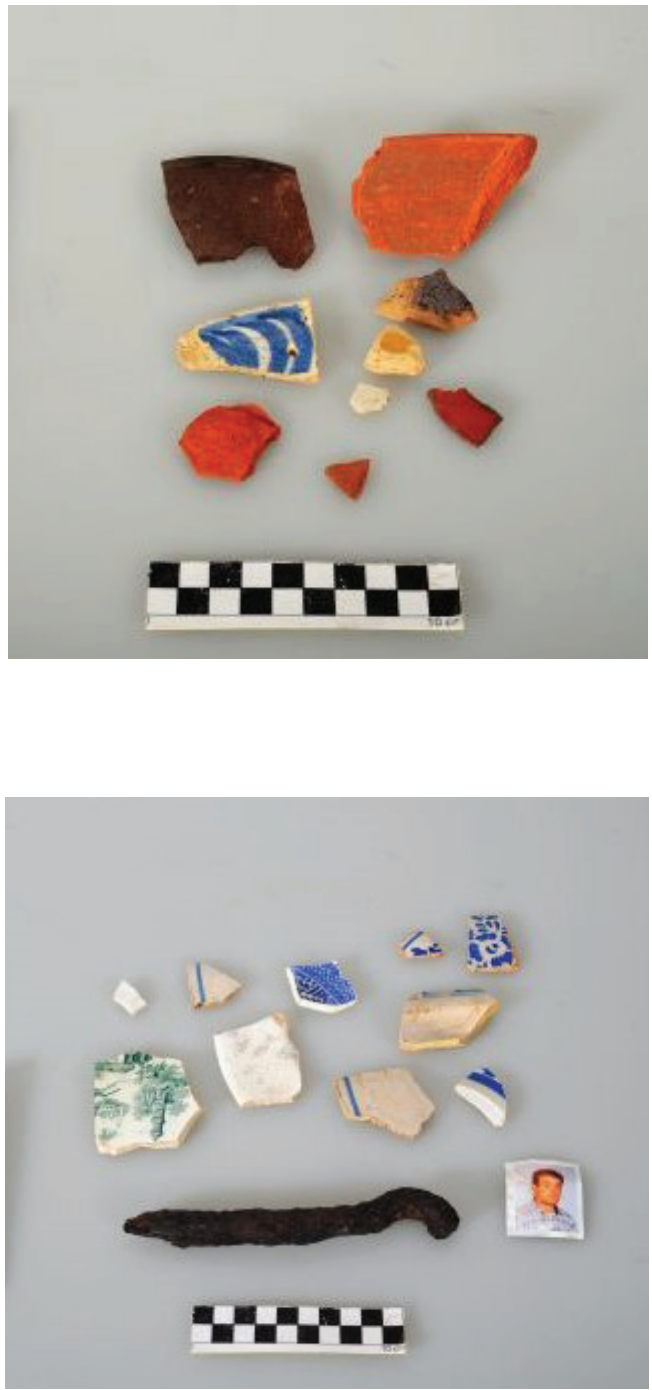

Figura 9-Material arqueológico exumado na Casa de João Dias, passível de datação entre o século XVI e o XVII; Autor: Direção Regional da Cultura dos Açores.

Figura 10 - Material arqueológico exumado na Casa de João Dias, passível de datação entre o século XIX e o XX; Autor: Direção Regional da Cultura dos Açores. 



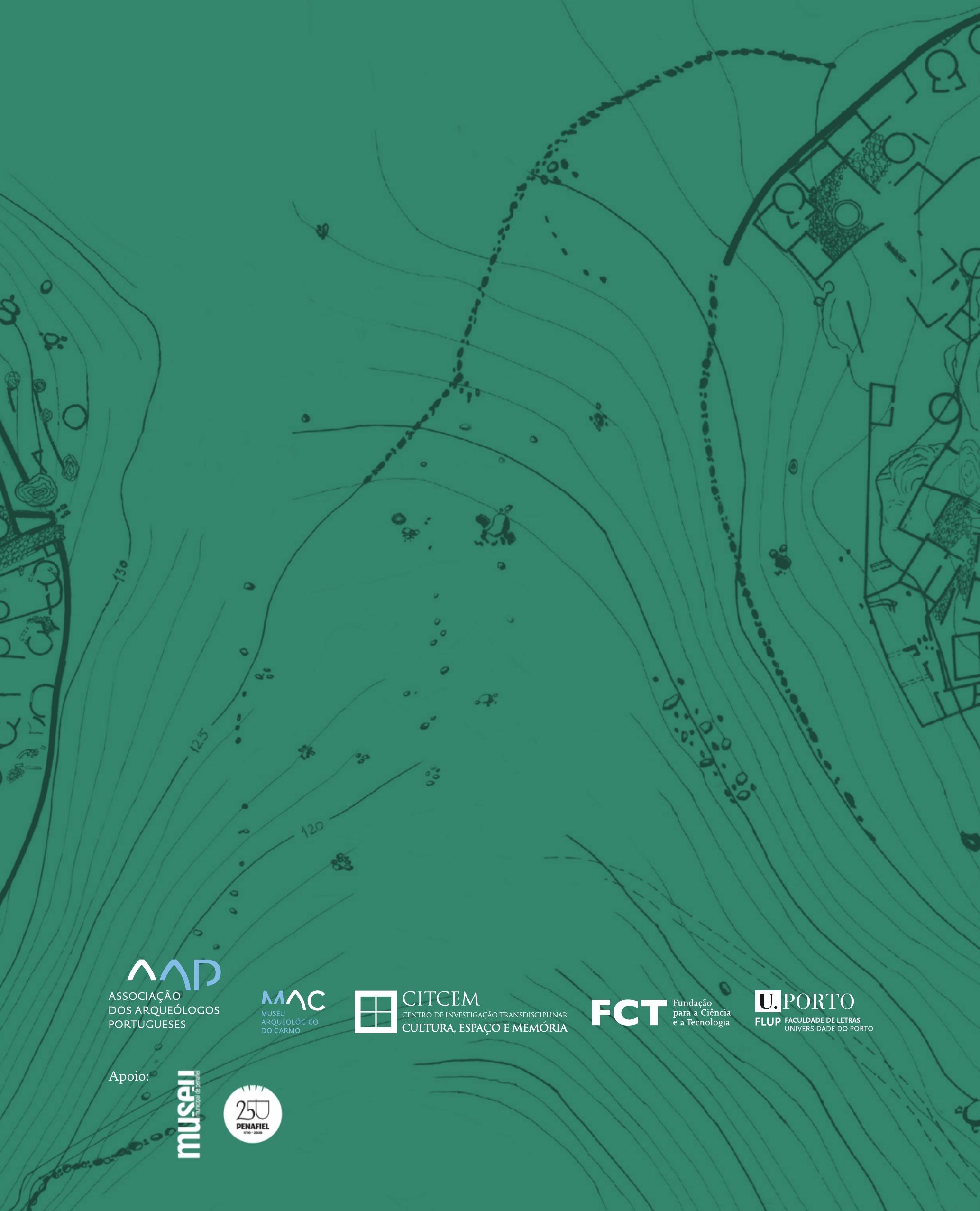

